\title{
KEHIDA-FÖVENYES 8-9. SZÁZADI NÉPESSÉGÉNEK TÖRTÉNETI EMBERTANI VIZSGÁLATA
}

Kiss Krisztián ${ }^{1,2}$, Szeniczey Tamás ${ }^{1,2}$, Marcsik Antónia ${ }^{3}$, Szvák Enikö3 ${ }^{3}$ Karlinger Kinga ${ }^{4}$, Mészáros Kis Zsuzsanna ${ }^{5}$, Szabó Lénárd ${ }^{6}$, Sklánitz Antal ${ }^{6}$, Buczkó Krisztina ${ }^{7,8}$, Szőke Béla Miklós ${ }^{9}$ és Hajdu Tamás ${ }^{1,2}$

${ }^{1}$ Eötvös Loránd Tudományegyetem, Embertani Tanszék, Budapest; ${ }^{2}$ Magyar Természettudományi Múzeum, Embertani Tár, Budapest; ${ }^{3}$ Szegedi Tudományegyetem, Embertani Tanszék, Szeged; ${ }^{4}$ Semmelweis Egyetem, Radiológiai Klinika, Budapest; ${ }^{5}$ Semmeilweis Egyetem, ETK, Budapest; ${ }^{6}$ Continental Automotive Hungary Kft., Központi Minőségbiztosítási Labor, Budapest; ${ }^{7}$ Magyar Természettudományi Múzeum, Növénytár, Budapest; ${ }^{8}$ Ökológiai Kutatóközpont, Duna-kutató Intézet, Budapest; ${ }^{9}$ Magyar Tudományos Akadémia, Régészeti Intézet, Bölcsészettudományi Kutatóközpont, Budapest

Kiss K., Szeniczey T., Marcsik A., Szvák E., Karlinger K., Mészáros Kis Zs., Szabó L., Sklánitz A., Buczkó K., Szőke B.M., Hajdu T.: Anthropological data to the late Avar Period in Zala county - Examination of Kehida-Fövenyes (8-9th century). In our work, 167 individuals from the Late Avar Period cemetery of Kehida-Fövenyes (8-9th century) were analysed. Altogether 65 children, 36 males and 50 females were examined, however in the case of 16 adults the sex determination was not possible. The newborn age group (0-1 year) is underrepresented in the cemetery. A biological imbalance can be observed between the ratio of males and females. According to the demographic data and pathological changes related to lifestyle and haematological aetiology, sex difference can be seen in the case of adult individuals. Females possessed a higher value of probability of death in almost every age group, and they also were more often affected by haematological disorders than males. The aforementioned phenomena can be related to the fact that women had to deal with physiological and pathophysiological stress originated from pregnancy and menstruation. During the taxonomical analysis, no individuals with clear Mongolid ancestry were identified. However, many skulls determined as Europid ancestry possesses Mongolid traits. The population is mostly characterized by dolichokran skull as Cromagnoid-A and Mediterranean were the most common types. Based on craniometric measurements it was possible to compare the population of Kehida-Fövenyes to other communities from this region what can shed a light of their biological relations. According to the biodistance calculations, males and females might share a different origin, since females showed a closer relation to the Early Avar Period population of the region. While males were rather connected to the Late Avar Period population of present-day Somogy county. During paleopathological investigations, a possible case of leprosy was identified based on the morphological alterations. In more cases paleoradiological investigations were also performed to provide a more reliable diagnosis.

Keywords: Avar Period; Paleodemography; Paleopathology; Craniometrics; Taxonomy; Leprosy; Metastatic cancer; Radiology; Microscopy.

\section{Bevezetés}

A Kr. u. 568-ban a Kárpát-medencét elfoglaló avarok szállásterületük nyugati határvidékét, a Dunántúl délnyugati szélét a velük itt megtelepedő szlávokkal együtt 
népesítették be (Pohl 2018). Az Avar Kaganátus fennállása idején (568-811) a térségben egy kevert kultúrájú népesség élt, amelyet a „Pókaszepetk-Zalakomár csoport” név alatt foglalhatunk össze (Szőke 2002). A csoportba tartozó temetők (Kehida-Tsz. Major, Kehida-Fövenyes, Pókaszepetk, Söjtör, Zalakomár) legjellemzőbb vonása a birituális temetkezés, amikor az avarok gyakran lovas és fegyveres csontvázas temetkezései mellett a szlávok urnába vagy földbe vájt sekély gödörbe temetett, hamvasztásos rítusa is fellelhetö. A kétféle rítus egyetlen temetőn belül egy időben, néha egyetlen sírban (a csontvázas sírba utólag betemetett hamvasztásos sír formájában), nagyobb részt azonban térben is elkülönült csoportokban észlelhető a 6. század végétől/7. század elejétől egészen a 9. század közepéig (Szőke 2002, 2003). A 9. század első harmadában a térség a Karoling birodalom fennhatóság alá került, népessége megkeresztelkedett, és 840-től az új hatalmi központ, Mosaburg/Zalavár köré települt. Itt a népesség részben egyszerü soros, ún. szolgálónépi temetőkbe (Garabonc-Ófalu I-II, EsztergályhorvátiAlsóbárándpuszta, Keszthely-Fenékpuszta), részben az ekkor épült templomok köré temetkezett (Szőke 2014).

A Kárpát-medencébe érkező avarok biológiai jellegük és etnikai összetétel szempontjából is rendkívül heterogének voltak. Nem csak az útjuk során hozzájuk csatlakozó csoportok, de a letelepedéskor helyben talált (autochton) népességek asszimilációja okán is (Lipták 1959). Éry Kinga (1982) összefoglaló munkájában az avar kori népességet embertani sajátosságaik alapján négy regionális csoportba osztotta: DunaTisza közi, kelet-dunántúli, nyugat-dunántúli és északnyugat-dunántúli csoportokba. Vizsgálatában szerepelt a Pókaszepetk-Zalakomár csoport egyik névadó temetője, Pókaszepetk is.

A Nyugat-Dunántúlon élt avar kori egyének hosszú, keskeny és magas agykoponyával, alacsony és középszéles arccal, szintén alacsony és középszéles szemüreggel és középszéles orral rendelkeztek. Ha az Éry Kinga által elkülönített négy avar kori Kárpátmedencei régiót/csoportot összevetjük egymással, akkor a nyugat-dunántúli csoport rendelkezett a leghosszabb, legmagasabb és legkeskenyebb koponyával, illetve legkeskenyebb és legalacsonyabb arccal. Leírása alapján a Nyugat-Dunántúl föképpen europidok által lakott vidék volt, kisebb mongolid jegyeket is mutató közösségekkel. Az Éry (1982) által közölt mintában viszont nem volt europomongolid jellegeket mutató egyén.

Éry (1982) eredményei szerint a Nyugat-Dunántúl népessége kapcsolatban volt az észak-nyugati csoport közösségeivel, de a kelet-dunántúli populációkkal nem. Ennek valószínüleg politikai vagy etnikai, és nem földrajzi okai lehettek. Fóthi (1984) eredményei alapján ugyanakkor egységesnek gondolja a Kelet- és Nyugat-Dunántúlt. A legújabb kraniometriai eredmények alapján a Dunántúl délnyugati és keleti része között állhatott fenn szorosabb biológiai kapcsolat (Szeniczey 2019).

Vizsgálatunk célja Kehida-Fövenyes késő avar kori populációjának biológiai antropológiai szempontú rekonstrukciója, valamint további adatok szolgáltatása a késő avar kori nyugat-dunántúli régió embertani ismereteihez. Mindezek megvalósításához az anyagon klasszikus embertani (paleodemográfia, taxonómia, kraniometria) és paleopatológiai vizsgálatokat végeztünk el.

\section{Anyag és módszer}

A vizsgálat anyagát a késő avar kori (8. század utolsó harmadára - 9. század első felére keltezhető) Kehida-Fövenyes embertani anyaga képezte. Az 1992-ben felfedezett 
temető feltárása Szőke Béla Miklós vezetésével történt 1994 és 2001 között. A 141 síros temetőt nem csak a nagyszámú padmalyos temetkezések és lovas sírok teszik különlegessé (Szőke és Vándor 2001; ásatási napló), de a birituális temetkezési mód is. Ezeknek a jellegzetességeknek egyetlen sírban koncentrálódott példája a temető 20 . sírja, ahol egy padmalyos lovas sírban az elhunyt felnőtt férfi hamvasztásból visszamaradt és feltehetően egy vászondarabba tekert, kalcinálódott csontjait egy koporsó közepébe helyezve temették el (Szőke 2004).

A vizsgált maradványok a Magyar Természettudományi Múzeum (MTM) Embertani Tárának gyüjteményében a 2017.4.1-22; 2018.2.1-110 és 2019.1.1-37 leltári számok alatt találhatók meg. A 2019.1.29-es és 2019.1.34-es leltári számú egyének maradványait nem lehetett sírhoz kötni, illetve egymástól elkülöníteni, így a szériában szórványként szerepelnek. Összesen 167 egyén maradványát lehetett külön individuumként vizsgálni.

A klasszikus embertani feldolgozás során a morfológiai nem meghatározásához Éry és munkatársai (1963) módszerét alkalmaztuk. Rossz megtartású eseteknél, amennyiben lehetséges volt, figyelembe vettük a humerus disztális végének sajátságait (Rogers 1999), illetve az állkapocs ágának lefutását is (Loth és Henneberg 1996). Az életkor becsléséhez vizsgáltuk a bordák szternális végének alaktani sajátságait (Iscan és mtsai 1984, 1985), valamint a szeméremcsont facies symphysialis-ának morfológiai jellegeit Brooks és Suchey (1990), illetve Todd $(1920,1921)$ munkáit alapul véve. A facies auricularis vizsgálatát korbecslés céljából mind makroszkóposan, mind sztereomikroszkóposan végeztük, hogy jellegeik alapján a Lovejoy és mtsai (1985) módszerét pontosító Buckberry és Chamberlain (2002) által definiált korstádiumokba oszthassuk. Felnőtteknél a koponyán található jellegek közül korbecslésre annak külső felszíni varrat elcsontosodáson alapuló Meindl és Lovejoy (1985) módszerét, illetve Mann és mtsai (1991) által javasolt szájpadvarratok elcsontosodását vettük figyelembe.

Magzatok és újszülöttek esetén Fazekas és Kósa (1978) irányelve szerint történt a kor becslése. A 14 évesnél fiatalabb gyermekek esetén Schour és Massler (1941), illetve Ubelaker (1989) fogazatot elemző módszereit alkalmaztuk. Szintén gyermekek esetében a hosszúcsontok külön-külön dimenzióin alapuló módszereket alkalmaztunk a kor becslésére: Stloukal és Hanáková (1978) szerint a csonthosszt, valamint Bernert és munkatársai (2007, 2008) szerint a hosszúcsontok átmérőjét vettük figyelembe. Gyermekek és fiatal felnőttek esetében az epi- és apofízis fúgák vizsgálatát is felhasználtuk korbecslésre (Schinz és Case 1952, Ferembach és mtsai 1979).

A biológiai életkorcsoportokat Martin és Saller (1957) szerint definiáltuk: Neonatus (0-1 év), Infans I. (2-6 év), Infans II. (7-14 év), Juvenis (15-19 év), Adultus (20-39 év), Maturus (40-59 év), Senium (60+ év).

A kraniometriai és oszteometriai vizsgálatokhoz a Martin és Saller (1957) által leírt méreteket vettük fel, a testmagasság becslését Sjøvold (1990) instrukciói szerint végeztük el. A koponya indexek szerinti osztályozást Alekszejev és Debec (1964), a taxonómiai elemzést Lipták (1965) útmutatása alapján végeztük.

Kehida-Fövenyes vizsgálata közben mért koponyaméretek közül tízet (M1, M8, M9, M17, M45, M48, M51, M52, M54 és M55) hasonlítottunk össze a szakirodalomban publikált egyéni adatokkal. Az összehasonlító vizsgálatba azokat a koponyákat vontuk be, amelyek esetében a kiválasztott 10 jelleg közül legalább 9 vizsgálható volt. A hiányzó koponyaméreteket temetőnként külön számolva a méretek közötti lehetséges összes lineáris regresszió log-likelihood értékének súlyozott átlagával pótoltuk ki. A koponyaméretek Darroch és Mosimann (1985) szerinti transzformációja után az 
outliereket a többváltozós normalitási centrumtól vett Mahalanobis távolságokkal szürtük ki 99\%-os konfidenciaszint mellett. A lelöhelyek közötti biológiai távolságot Mahalanobis távolsággal (1936) adtuk meg, amelyhez a transzformált adatokból képzett kovariancia mátrixot használtuk fel. Ez a metrika a minimum genetikai távolsággal jól korreláló eredményt ad (Williams-Blangero és Blangero 1989). Az adott páronkénti távolságok szignifikanciájának megállapításához Sjøvold (1975) módszerét alkalmaztuk. A kapott távolságmátrixok osztályozását hierarchikus klaszterelemzés csoportátlag (UPGMA) algoritmusával végeztük el, majd dendrogrammal ábrázoltuk. Azt, hogy a mátrixot az adott algoritmus mennyire pontosan képes ábrázolni gráfként, a kofenetikus korreláció értéke alapján tudhatjuk meg. Esetünkben a korrelációs értékek 0,8 fölött voltak, amely alapján megbízható gráfábrázolást kaptunk. Az összehasonlítás során használt adatkezelési és statisztikai módszereket R szoftverkörnyezetben alkalmaztuk.

A paleopatológiai feldolgozás során az elváltozásokat morfológiai alapon diagnosztizáltuk, amely során Ortner (2003), Aufderheide és Rodríguez-Martin (1998), Mann és Hunt (2005), illetve Waldron (2008) munkáit vettük alapul. A radiológiai felvételeket Chhem és Brothwell (2008), valamint a Fráter (2015) és a Lombay (2013) szerkesztésében megjelent könyvek alapján elemeztük. Az anatómiai variációk felismerését Mann és munkatársai (2016), valamint Keat és Anderson (1994) szerint végeztük. Az adatok digitalizálása és elemzése során Bernert (2005) paleoantropológiai programcsomagját használtuk fel. A demográfiai vizsgálatok során az újszülöttek számának korrekciója Coale és Demény (1966) modellje alapján történt. A statisztikai munkálatokat $\mathrm{R}$ fejlesztői környezetben végeztük el.

A klasszikus embertani vizsgálatok bizonyos esetekben kiegészültek radiológiai és mikroszkópos vizsgálatokkal is. A klinikai CT felvételek a Semmelweis Egyetem Radiológiai Klinikáján Phillips Ingenuity eszközzel készültek, míg az ipari CT vizsgálatokat a Continental Automotive Hungary Kft. Központi minőségbiztosítási labor GE, pheonix V/tomex/m müszerével végeztük el. A klinikai radiológiai felvételek megtekintéséhez és további rekonstrukciók készítéséhez az ingyenes RadiAnt DICOM Viewer, a szintén ingyenes synedra View Personal, míg az ipari CT felvételek elemzése céljából az ingyenes myVGL 3.2.3 programokat használtuk. Az MTM Növénytárában megvalósult pásztázó elektronmikroszkópos vizsgálat HitachiS-2600N típusú géppel történt.

\section{Vizsgálati eredmények és megvitatásuk}

A demográfiai elemzés eredményei

Munkánk során 167 egyén maradványait vizsgáltuk, köztük három hamvasztásos rítussal eltemetett egyénét (ltsz: 2017.4.20, 2019.1.26, 2019.1.27). A 36 férfit, 50 nőt és 81 ismeretlen nemű egyént tartalmazó széria korcsoportok szerinti megoszlását az 1. táblázat mutatja. A vizsgált egyének alapadatait (leltári szám, sírszám, életkor, nem, megtartottság) az Anthropologiai Közlemények honlapjáról letölthető elektronikus mellékletben található M1. táblázatban adjuk meg (Elektronikus Függeléktár). A 81 meghatározhatatlan nemü személyből 65 subadult kategóriába tartozó egyén volt. Az Infans I-es korcsoportba 37 egyén, összesen a populáció $22 \%$-a tartozott. Ez az arány azonban biztosan nagyobb lehetett a hajdani populációban, mivel az újszülöttek alulreprezentáltsága egy jól ismert jelenség a történeti embertani szériákban (Acsádi és Nemeskéri 1970). 
A részletesebb paleodemográfiai elemzésre 11 rossz megtartású lelet miatt összesen 156 egyén volt alkalmas. A demográfiai adatokat élettáblákba (2. táblázat, elektronikus melléklet: M2-3. táblázat) rendszereztük.

1. táblázat. Kehida-Fövenyes népességének korcsoportok és nemek szerinti megoszlása Table 1. Age and sex distribution of Kehida-Fövenyes population

\begin{tabular}{lccrc}
\hline $\begin{array}{l}\text { Korcsoportok }- \\
\text { Age groups }\end{array}$ & $\begin{array}{c}\text { Férfiak }- \\
\text { Male }\end{array}$ & $\begin{array}{c}\text { Nök }- \\
\text { Female }\end{array}$ & $?$ & $\begin{array}{c}\text { Összesen }- \\
\text { Altogether }\end{array}$ \\
\hline Infans I. & 0 & 0 & 37 & 37 \\
Infans I./II. & 0 & 0 & 3 & 3 \\
Infans II. & 0 & 0 & 12 & 12 \\
Infans II./Juvenis & 0 & 0 & 7 & 7 \\
Juvenis & 0 & 1 & 4 & 5 \\
Juvenis/Fiatal - young adultus & 0 & 2 & 0 & 2 \\
Adultus & 8 & 21 & 3 & 32 \\
Adultus/Maturus & 11 & 16 & 0 & 27 \\
Maturus & 15 & 10 & 0 & 25 \\
Maturus/Senilis & 1 & 0 & 0 & 1 \\
Senilis & 0 & 0 & 0 & 0 \\
Adultus/Maturus/Senilis & 0 & 0 & 10 & 10 \\
$?$ & 1 & 0 & 5 & 6 \\
Összesen/Altogether & 36 & 50 & 81 & 167 \\
\hline
\end{tabular}

2. táblázat. Kehida-Fövenyes teljes népességének Coale és Demény (1966) szerinti újszülöttkori korrekció nélküli halandósági táblázata

Table 2. Life table of Kehida-Fövenyes without newborn-correction (Coale and Demény 1966)

\begin{tabular}{lrrrrc}
\hline $\begin{array}{l}\text { Korcsoportok (év) - } \\
\text { Age groups (years) }\end{array}$ & (Dx) & (dx) & (lx) & (qx) & (ex) \\
\hline 0 & 1,60 & 1,04 & 100,00 & 0,01 & 25,86 \\
$1-4$ & 25,50 & 16,30 & 98,96 & 0,16 & 25,12 \\
$5-9$ & 20,80 & 13,33 & 82,66 & 0,16 & 25,68 \\
$10-14$ & 8,80 & 5,66 & 69,33 & 0,08 & 25,14 \\
15-19 & 7,40 & 4,74 & 63,67 & 0,07 & 22,15 \\
Gyermekek együttesen - & 61,1 & 41,07 & - & - & - \\
Subadults together & & & & & \\
20-24 & 11,80 & 7,55 & 58,93 & 0,13 & 18,73 \\
25-29 & 9,40 & 6,00 & 51,38 & 0,12 & 16,12 \\
30-34 & 11,80 & 7,55 & 45,38 & 0,17 & 12,92 \\
35-39 & 15,70 & 10,07 & 37,83 & 0,27 & 10,00 \\
$40-44$ & 17,00 & 10,89 & 27,76 & 0,39 & 7,72 \\
45-49 & 13,30 & 8,54 & 16,87 & 0,51 & 6,08 \\
50-54 & 7,90 & 5,03 & 8,33 & 0,60 & 4,76 \\
55-59 & 4,50 & 2,87 & 3,30 & 0,87 & 3,20 \\
60-64 & 0,60 & 0,40 & 0,43 & 0,93 & 2,85 \\
65-69 & 0,00 & 0,03 & 0,03 & 1,00 & 2,50 \\
Felnőttek együttesen - & 95,00 & 58,93 & - & - & - \\
Adults together & & & & & \\
Teljes népesség - Altogether & 156,10 & 100,00 & - & - & - \\
\hline
\end{tabular}


A mortalitási görbe az 1. ábrán látható, míg a várható élettartam (M1. ábra) és túlélési görbék (M2. ábra) a mellékletben találhatók. A korrekció nélküli halandósági tábla (2. táblázat) alapján az alábbi következtetések vonhatók le az egész populációra nézve: Gyermekek esetén az 1-4 éves, illetve 5-9 éves korcsoportoknál volt a legmagasabb a halálozási valószínűség $(0,16)$. A populáció vizsgálható részének $41 \%$-a, azaz 20 gyermek vesztette életét a felnőttkor előtt. A várható élettartam értéke a korcsoportok elörehaladtával fokozatosan csökken, születéskor 26 év, míg a felnőtt korba lépéskor 18,5 év volt. Felnőtteknél 35 és 44 éves kor között a legnagyobb az elhunytak száma.

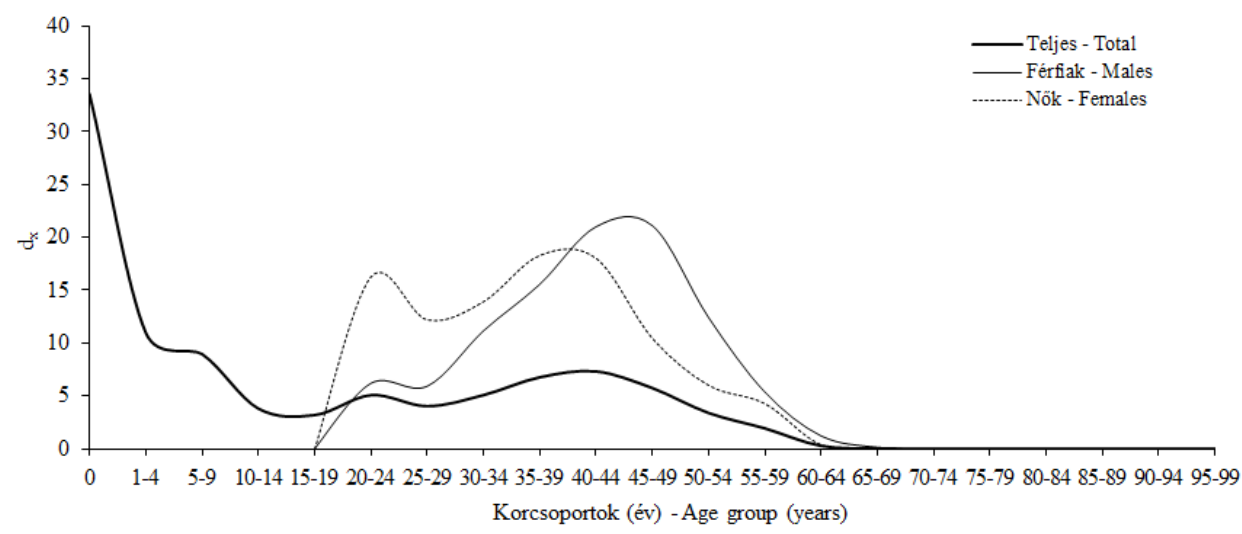

1. ábra: Kehida Fövenyes népességének mortalitási görbéje Coale és Demény (1966) korrekciója után

Fig. 1: Mortality curve of Kehida-Fövenyes (after Coale and Demény's newborn-correction)

Az újszülöttek számának korrekciója Coale és Demény (1966) modelljével történt, amely számolást Bernert (2005) programcsomagjával végeztük el. Az így kapott halandósági tábla (M2. táblázat) alapján az alábbi következtetések vonhatók le az egész populációra nézve: A 0 és 1 éves koruk között lévő gyermekek elhalálozási valószínüsége 0,34, később 1 és 9 éves kor között 0,16. A serdülőkorba lépő egyéneknél ez még tovább csökken. A populáció közel $60 \%$-a vesztette életét a felnőttkor előtt. A várható élettartam értéke 9 éves korig növekedett, majd ezután a korcsoportok előrehaladtával fokozatosan csökkent: ez születéskor 17,5 év, a felnőtt kor kezdetén pedig 18,5 év volt. A mortalitási görbe (1. ábra) 40-44 éves kor között csúcsosodik ki felnőttek esetén.

A nemek szerinti élettábla (M3. táblázat), valamint a korrekció által módosított mortalitás (1. ábra), várható élettartam (M1. ábra) és túlélés görbéje (M2. ábra) alapján a következőket állapíthatjuk meg. Az elhalálozási ráta maximuma férfiak esetében 40-44 éves, míg nőknél 35-39 éves korra tehető. Nőknél és a férfiaknál is bimodális jellege van a halálozási ráta görbéjének (1. ábra): férfiaknál a 20-24 éves, valamint 40-44 éves korcsoportnál, míg nőknél egy a maturus (35-40 éves kor), egy pedig a fiatal adultus (20-24 éves kor) életszakaszban. Ennek oka a nők életét veszélyeztető szülésben kereshető. Férfiaknál az adultus korcsoport elején a várható élettartam 21 év, míg nőknél csak 17 év volt. A férfiak és nők halálozási valószínüségében jól látható a különbség, hiszen utóbbiak esetében - a 45-55 éves korcsoportokat leszámítva - szinte a teljes felnőtt életszakasz során magasabb érték jellemző. Ennek oka lehet egyrészt a nők nagyobb aránya mintában, vagy szervezetük nagyobb fokú sebezhetősége a környezeti faktorokkal 
szemben. A fokozott kitettséget valószínüleg a szülés és terhesség miatti fiziológiás és patológiás stressznek tulajdoníthatjuk.

A combcsont alapján történő testmagasság becslésére összesen 23 férfi és 32 nő maradványa volt alkalmas. Sjøvold (1990) módszerét alkalmazva az eredmények alapján a férfiak átlagos magassága $170,31 \mathrm{~cm}$, míg a nőké $158,96 \mathrm{~cm}$ volt (3. táblázat). Mindkét nem átlagértéke a Martin (1957) szerinti magas (férfiak: 167-169,9 cm; nők: 156-158,9 $\mathrm{cm})$ kategóriába esik. A vizsgált egyének oszteometriai adatait az elektronikus melléklet M4-5. táblázataiban adtuk meg.

Kehida-Fövenyes népességének férfi és női tagjai beleillenek mind a Kárpátmedencei, mind a dunántúli átlagértékek sorába (Éry 1998).

A vizsgálható személyek nagy része a közepes, nagyközepes és magas kategóriába esett (elektronikus melléklet: M6. táblázat).

3. táblázat. A testmagasság becslésének eredményei cm-ben kifejezve - összehasonlításképpen a Dunántúl és Kárpát-medence avar kori populációinak átlagértéke is látható (Éry 1998)

Table 3. Results of estimation of height given in $\mathrm{cm}$ - for comparison the mean value of Avar Period's Transdanubia and Carpathian Basin can be seen (Éry 1998)

\begin{tabular}{lccccccccc}
\hline & $\begin{array}{c}\text { Vizsgálható } \\
\text { esetek - } \\
\text { Investigable } \\
\text { cases }\end{array}$ & $\mathrm{V}_{\max }$ & $\mathrm{V}_{\text {min }}$ & $\begin{array}{c}\text { Átlag - } \\
\text { Mean } \\
\text { (M) }\end{array}$ & SD & SD/M & $\begin{array}{c}\text { Dunántúl } \\
- \text { Trans- } \\
\text { danubia }\end{array}$ & $\begin{array}{c}\text { Kárpát-m.- } \\
\text { Carpathian } \\
\text { Basin }\end{array}$ \\
\hline Férfiak-Males 25 & 23 & 185,97 & 156,97 & 170,31 & 6,33 & 3,72 & 168,70 & 167,70 \\
Nök-Females 36 & 32 & 174,86 & 149,79 & 158,96 & 5,23 & 3,29 & 158,10 & 157,70 \\
\hline
\end{tabular}

A kraniometriai elemzés és összehasonlítás eredményei

Összesen 24 férfi és 39 nő koponyáját lehetett az elektronikus melléklet M7. táblázatában bemutatott Martin (1957) féle méretek felvételére és indexek kiszámolására felhasználni. A vizsgált egyének kraniometriai adatait az elektronikus melléklet M8-9. táblázataiban adjuk meg. Az eredmények alapján a férfiak átlagos kraniometriai jellemzői a következők: agykoponyájuk a hosszúság-szélesség jelzője (8:1) szerint dolichokran, és a hosszúság-magasság jelzője (17:1) alapján orthrokran. A koponya szélességének aránya a magassághoz (17:8) viszonyítva pedig akrokran jellegü. A fülmagasságot a koponyahosszúság százalékában kifejezve (20:1) hyperchamaekran, míg a koponya szélességéhez hasonlítva (20:8) hypertapeinokran jelleget kapunk. A transversalis frontotemporalis jelző (9:8) alapján a homlok eurymetop. A morfológiai arcjelző (47:45) és felsőarcjelző (48:45) szerint az arckoponya közepesen magas (mesoprosop és mesen). Az orbita arányaiban (52:51) alacsony (chamaekonch). Az orr (54:55) mesorrhin, a szájpad szélessége a hosszúságához viszonyítva (63:62) mesostaphylin (közepes).

A nők koponyája hosszú (8:1), magasságuk a hosszúsághoz képest (17:1) orthokran, a szélességhez viszonyítva $(17: 8)$ akrokran. A fülmagasságot összemérve a koponya hosszúságával (20:1) és szélességével (20:8) hyperchamaekran és hypertapeinokran átlagértéket kapunk. A homlok közepesen széles (9:8). Az egészarc mesoprosop (47:45), míg a felsőarc (48:45) széles és alacsony (euryen). A szemüreg (52:51) mesokonch, az orr pedig széles (54:55). A szájpad szélessége hosszúságához viszonyítva (63:62) brachystaphylin. 
Nyolc férfi és szintén nyolc nő koponyáját lehetett a kraniometriai alapú biológiai távolságszámításba bevonni, hogy Kehida-Fövenyes népességét az alábbi temetőkkel összehasonlíthassuk:

A mai Zala megye területéről Keszthely-Ödenkirche-Flur (6-7. század; Mende és Kirinó 2014), Pókaszepetk-Mesterföldek (6-7. század; Bottyán 1975), Keszthelykörnyéke (6-8. század; Varga és mtsai 2003), Keszthely-Belváros (7-8. század; Wenger 1977), Garabonc Ófalu I. (8-9. század; Éry 1992), és Zalaszabar-Dezsősziget (9. század; Éry 1992).

A mai Somogy megye területéröl Kaposvár 61-es út 26. lelőhely (7-8. század; Évinger és Bernert 2005), Siófok-Kiliti (7-8. század; Suskovics 1993), KaposvárFészerlakpuszta (8-9. század; Fóthi 1988), Toponár 40-es őrház (8-9. század; Wenger 1974), Kereki-Homokbánya (8-9. század; Bernert 2003). A mai Veszprém megye területéröl Jutas és Öskü (Bartucz 1930) került be az összehasonlító anyagba.

Az összehasonlító kraniometriai elemzések alapján a csoportátlagok szerint KehidaFövenyes férfi népessége szignifikánsan különbözik Pókaszepetk férfi népességétől (4. táblázat). A Mahalanobis távolság alapján a három legközelebbi temető Keszthely Ödenkirche-Flur $(1,345)$, Kaposvár-Fészerlakpuszta $(1,442)$ és Kaposvár 61-es út 26. lh $(1,514)$. Kehida-Fövenyes női koponyái szignifikánsan különböznek Garabonc Ófalu I. közösségétől (3. táblázat). A három legközelebbi temető Keszthely-Fenékpuszta $(1,540)$, Pókaszepetk $(1,612)$ és Zalaszabar-Dezsősziget $(1,927)$ volt.

4. táblázat. A férfiak (vastaggal szedett értékek), illetve a nők (dőlten szedett értékek) összehasonlításából származó Mahalanobis távolságszámítás eredményei. Aláhúzással kiemelve a Holm-Bonferroni p-érték korrekció után szignifikánsan különböző értékek szerepelnek $(\mathrm{p}<0,05)$ Table 4. Results of Mahalanobis-distance calculations in males (in bold) and females (in italics).

Significantly different values (based on Holm-Bonferroni p-value correction, $\mathrm{p}<0.05$ ) are underlined

\begin{tabular}{|c|c|c|c|c|c|c|c|c|c|c|c|c|}
\hline & $\begin{array}{c}\text { Kapos } \\
61 .\end{array}$ & $\begin{array}{c}\text { K- } \\
\text { Fészer }\end{array}$ & $\begin{array}{c}\text { Top. } \\
40\end{array}$ & $\begin{array}{c}\text { K- } \\
\text { Föveny }\end{array}$ & $\begin{array}{l}\text { Póka- } \\
\text { szep }\end{array}$ & $\begin{array}{c}\text { S- } \\
\text { Kiliti }\end{array}$ & Garab & $\begin{array}{l}\text { Zala- } \\
\text { szabar }\end{array}$ & $\begin{array}{l}\text { K- } \\
\text { Hom }\end{array}$ & $\begin{array}{c}\text { K- } \\
\text { Város }\end{array}$ & $\begin{array}{c}\text { K- } \\
\text { Öden }\end{array}$ & $\begin{array}{c}\text { K- } \\
\text { körny }\end{array}$ \\
\hline Kapos 61. & & 2,760 & 1,844 & 2,251 & 2,313 & 3,178 & 2,510 & 2,380 & 2,123 & 2,224 & - & 2,738 \\
\hline K-Fészer & $\underline{2,058}$ & & 2,337 & 2,330 & $\underline{2,511}$ & 2,523 & $\underline{2,370}$ & 2,467 & 2,111 & $\underline{2,010}$ & - & $\underline{2,988}$ \\
\hline Top. 40 & $\overline{1,902}$ & 1,260 & & 2,003 & 1,610 & 2,552 & 2,164 & 1,841 & 1,242 & $\overline{1,383}$ & - & $\overline{2,202}$ \\
\hline K-Föveny & $\overline{1,514}$ & 1,442 & 2,103 & & 1,612 & $\overline{2,868}$ & $\overline{1,927}$ & 2,385 & 1,972 & 1,540 & - & 2,426 \\
\hline Pókaszep & $\underline{3,606}$ & $\underline{2,084}$ & $\underline{2,299}$ & $\underline{\mathbf{3}, 057}$ & & 2,180 & 1,744 & 2,036 & 1,585 & 0,862 & - & 1,953 \\
\hline S-Kiliti & $\underline{2,550}$ & $\underline{2,515}$ & 2,167 & $\underline{2,944}$ & $\underline{4,003}$ & & 2,077 & 1,932 & 1,974 & 2,136 & - & 2,094 \\
\hline Garab & $\overline{2,023}$ & $\overline{1,092}$ & 1,337 & $\overline{1,707}$ & $\overline{2,156}$ & 2,265 & & 1,127 & 1,890 & 1,382 & - & 2,477 \\
\hline Zalaszabar & 2,203 & 1,320 & 1,254 & 1,935 & 2,304 & 2,807 & 1,626 & & 1,552 & 1,799 & - & 2,578 \\
\hline K-Hom & $\underline{2,026}$ & 1,446 & 0,913 & 2,043 & $\underline{2,644}$ & 2,105 & 1,417 & 1,631 & & 1,537 & - & 1,756 \\
\hline K-Város & $\overline{2,004}$ & 1,455 & 1,091 & 2,165 & $\overline{2,889}$ & 1,909 & 1,415 & 1,609 & 1,043 & & - & 2,064 \\
\hline K-Öden & 1,984 & 1,272 & 1,755 & 1,345 & $\overline{2,277}$ & $\underline{3,203}$ & 1,571 & 1,850 & 1,881 & 2,108 & & - \\
\hline K-körny & $\underline{2,192}$ & 0,738 & 1,257 & 1,836 & 1,830 & $\overline{2,450}$ & $\mathbf{0 , 7 5 3}$ & 1,602 & 1,541 & 1,555 & 1,564 & \\
\hline
\end{tabular}

Lelőhelyek - Sites: Kapos 61.: Kaposvár 61-es út 26. lh - Kaposvár 61th road site 26, K-Fészer: KaposvárFészerlakpuszta, Top. 40: Toponár 40-es őrház - Toponár guardhouse 40, K-Föveny: Kehida-Fövenyes, Pókaszep: Pókaszepetk-Mesterföldek, S-Kiliti: Siófok-Kiliti, Garab: Garabonc Ófalu I., Zalaszabar: Zalaszabar-Dezsősziget, K-Hom: Kereki-Homokbánya, K-Város: Keszthely-Belváros - Keszthely downtown, K-Öden: Keszthely Ödenkirche-Flur, K-körny: Keszthely-környéke - Keszthely surroundings 
A közösségek közti távolsági viszonyokat férfiak (M3. ábra) és nők (M4. ábra) adatainak dendrogramként való ábrázolása mutatja. A gráfok alapján a nők egy halmazba kerültek a legtöbb Zala megyei sorozattal, a kehidai férfiak viszont nem csak egy közeli lelőhely, a Keszthely-Ödenkirche-Flur, de a Kaposvár 61-es út 26-os lelőhely férfi tagjaival alkotnak egy közös klasztert, és nem csoportosíthatók egybe azon temetőkkel, amelyekkel a nők közeli rokonságot mutatnak. Az ábrázolás alapján a nők esetében kimutatható biológiai kapcsolat a térség kora avar kori populációival, a férfiak viszont egy Zala-Mura köz térségén kívül elhelyezkedő populációval is közelebbi rokonságot mutatnak.

\section{A taxonómiai elemzés és összehasonlítás eredményei}

A vizsgált anyagban taxonómiai elemzésre összesen 55 felnőtt egyén koponyája volt alkalmas. A koponyafotók a tanulmány törzsszövegében (2-4. ábra) és az elektronikus mellékletben találhatók (M5-M36. ábra).

Férfiak esetén az europid földrajzi változat brachykran csoportjából pamíri jellegeket egy férfin lehetett megfigyelni. Egy másik a brachykran csoportba tartozó egyénnél pontosabb taxonómiai besorolást nem lehetett megadni. A dolichokran csoporton belül két-két férfi tisztán mediterrán és cromagnoid-A (2. ábra) jellegeket mutatott, míg egy nordikusat. Egy mediterrán és egy cromagnoid-A csoportba sorolható férfi esetén más, nem meghatározható europid csoportból származó taxonómiai elemeket lehetett megfigyelni. Négy férfi esetén csak az europid földrajzi változaton belüli dolichokran csoportba való tartozást lehetett megállapítani.
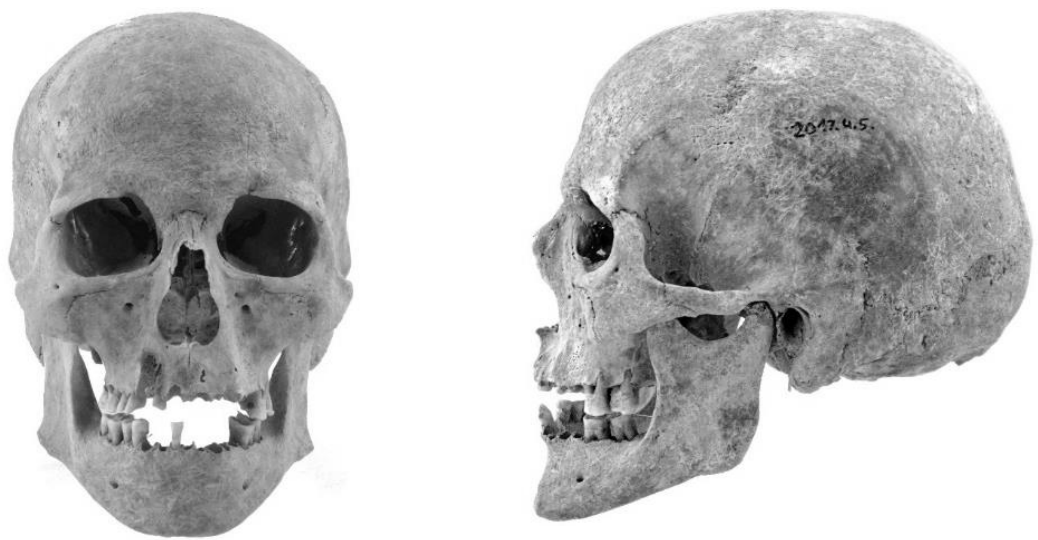

2. ábra: Egy 40-45 éves férfi (Kehida-Fövenyes, 7/A. sír, ltsz: 2017.4.5) koponyája elöl- és oldalnézetben - cromagnoid-A

Fig. 2: A 40-45 year-old male (Kehida-Fövenyes, grave no: 7/A, inventory no: 2017.4.5), anterior and lateral view - Cromagnoid-A

Férfiaknál 12 esetben lehetett a mongolid földrajzi változatra jellemző jegyeket felismerni a koponyán. Így hét a cromagnoid-A csoporthoz, illetve egy-egy a mediterrán, valamint pamíri taxonba tartozó férfi mutat mongolid jegyeket. Mongoloid vonások ismerhetők még fel egy a dolichokran csoportba tartozó egyénen, valamint egy mediterrán és cromagnoid jegyeket is viselö férfi esetében. 
A nök körében az europid földrajzi változat brachykran csoportjába két pamíri (3. ábra) és két olyan egyén sorolható, akiknél nem lehetett pontosabb taxonómiai besorolást megadni. A dolichokran csoportba három mediterrán típusú nőt osztottunk be. További egy egyén koponyája javarészt mediterrán jellegeket mutatott, azonban más meghatározhatatlan europid típus jegyeit is magán viselte. Rossz megtartásuk miatt tíz koponya pontos taxonómiai besorolását nem tudtuk kivitelezni: hét a dolichokran és három az europid csoportba besorolható egyén volt.

A férfiakhoz hasonlóan a nők közül is több egyén koponyáján lehetett mongolid jegyeket megfigyelni. Így három cromagnoid-A, három mediterrán (4. ábra), egy pamíri és egy cromagnoid-B egyén esetében.
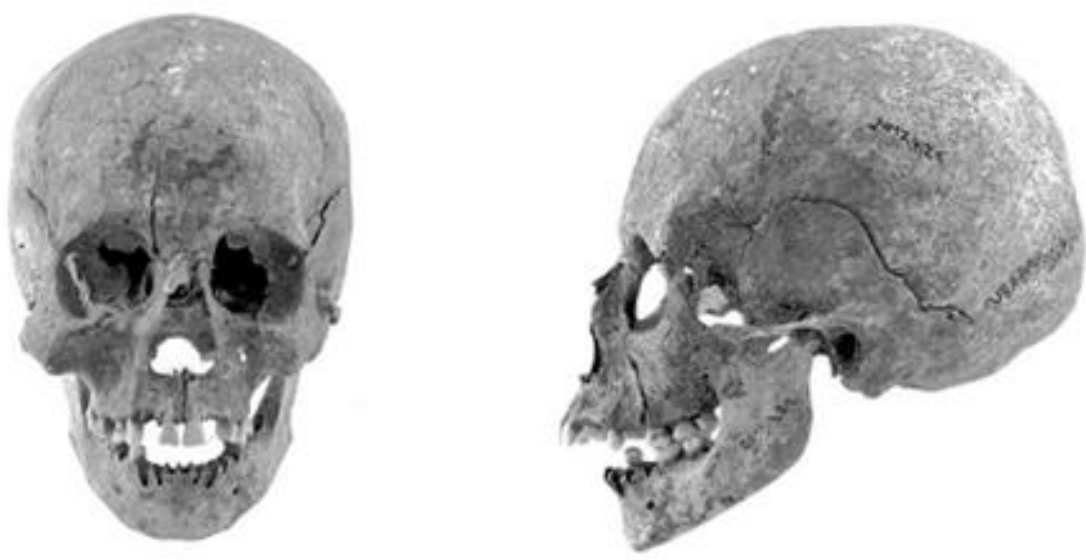

3. ábra: Egy 19-22 éves nő (Kehida-Fövenyes, 21. sír, ltsz: 2017.4.21) koponyája elől- és oldalnézetben - pamíri-X (mongoloid)

Fig. 3: A 19-22 year-old female (Kehida-Fövenyes, grave no: 21, inventory no: 2017.4.21), anterior and lateral view - Pamirian-X (Mongolid)
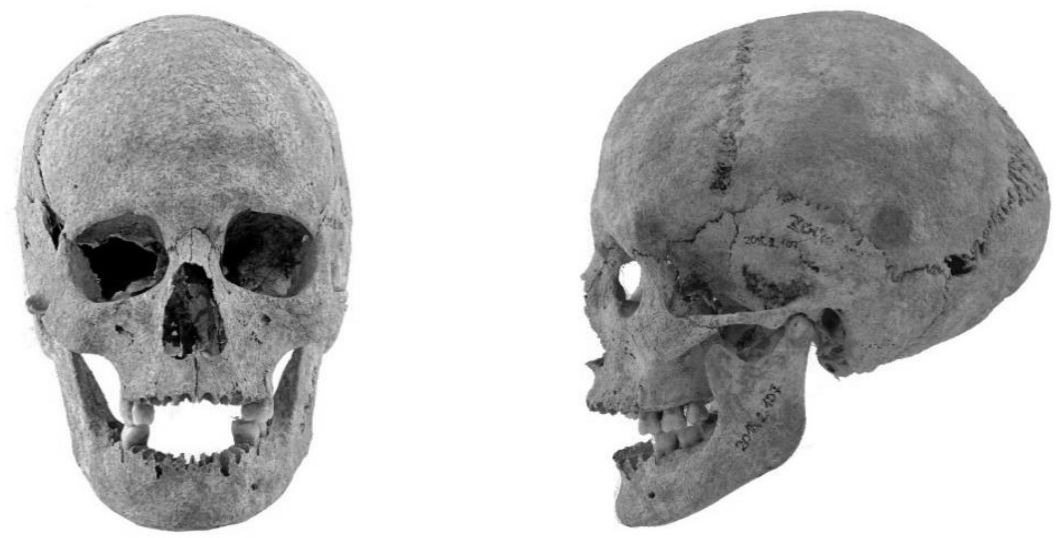

4. ábra: Egy 25-30 éves nő (Kehida-Fövenyes, 135. sír, ltsz: 2018.2.107) koponyája elöl- és oldalnézetben - mediterrán-X (mongoloid)

Fig. 4: A 25-30 year-old female (Kehida-Fövenyes, grave no: 135, inventory no: 2018.2.107), anterior and lateral view - Mediterranean-X (Mongoloid) 
Tisztán mongolid egyén nem került elő a vizsgált anyagból. Egy férfi és három női koponya dominánsan mongolid jelleg volt. Rossz megtartásuk miatt viszont pontos meghatározást nem lehetett megadni. Az említett három nő közül egy hosszú koponyával rendelkezett.

Egy meghatározhatatlan nemű felnőtt egyén a cromagnoid-B csoportba sorolható, ugyanakkor mongoloid jellegek is jelentkeztek arckoponyáján. Két gyermek esetén pedig lapátfogat találtunk.

Az összehasonlításhoz felhasznált szakirodalmi adatok (Kaposvár 61-es út, Évinger és Bernert 2005; Kereki-Homokbánya, Bernert 2003; Keszthely-Belváros, Wenger 1977; Kaposvár-Fészerlakpuszta, Fóthi 1988; Zalakomár-II, Éry 2001; Éry 1982 összefoglaló írása) alapján Kehida-Fövenyes népessége beleillik a régió késő avar kori populációinak taxonómiai képébe. Hasonlóan más populációkhoz az egyének többsége a dolichokran csoportba tartozik. Dominálnak benne a cromagnoid-A és mediterrán típusok. Éry Kinga (1982) összefoglaló leírása alapján a nyugat-dunántúli területeken csak kisebb mongolid közösségek ismertek (Mosonszentjános, Sopron, Bágyogszovát-Gyürhegy, Győr és Öskü). Jelenlegi tudásunk szerint a Dunántúl keleti részén nem ismert mongolid dominanciát mutató populáció. Általánosan is az europid változat dominál a dunántúli avar kori temetők leletanyagában. Kehida-Fövenyes esetén magas számban képviseltetik magukat olyan alapvetően europid koponyák, amelyeken több mongolid jelleget meg lehet figyelni. A kehidai temető különbözik az összehasonlított anyagtól.

A paleopatológiai elemzés eredményei

A vizsgálati anyagban három hamvasztott egyén (ltsz: 2017.4.20, 20. sír; 2019.1.26., 68. sír; 2019.1.27, 60. sír) szerepelt, de maradványaiknak rossz megtartási állapotuk miatt nem voltak alkalmasak paleopatológiai szempontú elemzésre.

Enthesopathiák. A vizsgálati anyagban több esetben figyeltünk meg a térdkalácsokon, sarokcsontokon és a vázrendszer egyéb területein (tuberositas ulnae/radii/tibiae/ glutealis/deltoidea, valamint linea aspera és linea musculi solei) manifesztálódó enthesopáthiás elváltozásokat, az anatómiai területekre vonatkozó gyakorisági adataikat nemre lebontva adjuk meg (M10. táblázat). A térdkalácsokon és sarokcsontokon kívül leggyakrabban a combcsont linea aspera és tuberositas glutealis részén volt kifejezett az izomtapadási érdesség. A M11. táblázatban az enthesopáthiás elváltozás által érintett férfiak, nők és ismeretlen nemü felnőtt egyének számát láthatjuk korcsoportonként megadva. Látható, hogy a kor elöre haladtával gyakoribb az elváltozások száma, amely vagy a fizikai munkavégzés vázrendszerre kifejtett hatásának vagy az idős korban történő degeneratív elváltozásoknak tudható be (Nikita 2017).

Ízületi rendellenességek. Történeti szériákban az osteoarthrosis deformans az egyik leggyakoribb elváltozás. A nőknél gyakoribbak voltak valamely nem a gerincben lévő ízületek kóros elváltozásai, mint a férfiaknál (M12. táblázat). Oka életmódbeli különbségből is fakadhat. Több esetben megfigyelhető volt az asepticus nekrózis egy fajtája, az osteochondritis dissecans. Gyermekeknél egy esetben, felnőtt férfiaknál hat, míg felnőtt nöknél három egyénnél lehetett találkozni ezzel a csonttani tünettel.

Munkánk során spondylosis deformans, spondylodiscitis, spondylarthrosis és Schmorl-hernia nyomait kerestük (M13. táblázat).

A spondylosis deformans férfiak körében általában gyakoribb (Aufderheide és Rodríguez-Martin 1998), amely a vizsgálati anyagban is kimutatható volt. Legnagyobb számban az ágyéki szakasz érintett mindkét nemnél (19 férfi és 17 nő), amely várható a gerinc mechanikai viszonyainak ismeretében. A férfiak thoracalis szakaszát gyakrabban 
érintette a kórkép. A M13. táblázat alapján nemi különbség valószínüleg a férfiak nagyobb fokú fizikai aktivitása miatt alakult ki, ami talán más jellegú fizikai megterhelésre utal. A spondylosis deformans életkortól és fizikai aktivitástól függő mivolta figyelhető meg, hiszen a magasabb életkorban gyakoribb mindkét nemnél (M14. táblázat).

Spondylodiscitis esetén nem láthatunk jelentős különbséget a nemeknél (M13. táblázat). Elképzelhető, hogy a gyulladások nem a fizikai aktivitással függnek össze, és ahogyan a szakirodalom is szerepel, fertőzések miatt jött létre (Waldron 2008). Feltételezhetjük viszont életkor függő megjelenését, hiszen döntő többségben maturus életkorban (6 férfi, 6 nő) fordult elő (M15. táblázat).

Spondylarthrosis, a csigolyanyúlványokon található kisízületek gyulladása mindkét nem esetében ( 8 férfi és 6 nő) a nyaki szakaszon volt a leggyakoribb (M13. táblázat), leggyakrabban a maturus életkorú egyéneket érintették (M16. táblázat).

A Schmorl-hernia (M13. táblázat) mindkét nem esetében a háti szakaszon gyakoribb. A kor és nem tekintetében nem mutatkozott jelentős különbség (M17. táblázat). Ezt a szakirodalmi adatok is alátámasztják (Dar és mtsai 2010, Németh 2010, Németh és mtsai 2015). Egy 13-15 éves gyermek ágyéki szakaszán volt ez az elváltozás jelen.

Hematogén elváltozások. A vérképzőszervi zavarokat a szemüreg, a fal- és nyakszirtcsont felszínén poroticus hyperostosis formájában azonosíthatjuk (Marcsik 1975, Józsa és Pap 1991, Nikita 2017). A felnőttek és gyermekek esetében is vizsgáltuk a poroticus elváltozások számát a két szemüreg, a két falcsont és a nyakszirtcsont esetében (M18. táblázat). A vizsgálati anyagban szinte kivétel nélkül a szemüregben volt látható poroticus elváltozás. Egy maturus korú (40-55 éves) nőnél lehetett megfigyelni a bal falcsonton a patológiát. A gyermekek nagyobb számban voltak érintettek, amelynek okai a kedvezötlen környezeti faktorok lehetnek. Nőknél gyakoribb a hematológiai rendellenességek száma (nőknél a vérszegénység gyakoribb kórkép a menstruáció és a terhesség miatt). Gyermekeknél két esetben a cribrotikus és egy esetben a trabecularis stádium fordult elő (M19. táblázat).

Anyagcsere betegségek. Vizsgálati anyagunkban 25 férfi, 36 nő és két ismeretlen nemü egyén esetén volt lehetőségünk a hyperostosis frontalis interna (HFI) meglétét vizsgálni (M20. táblázat). Három férfi, hét nő és egy ismeretlen nemű személy mutatta az elváltozás nyomait. A betegség teljes etiológiája kevésbé ismert, Jaffe (1975) szerint a szervezet így reagál a menopauza utáni hormonális változásokra. Western és Bekvalac (2017) meglátása szerint az androgének, az IGF-1 és az inzulin müködésében történő zavar fontos szerepet játszanak a betegség kialakulásában. Szeniczey és mtsai (2019) kutatása - azon túl, hogy tovább erösíti ezt a hipotézist - az alábbi következtetések levonására is lehetőséget adott: a HFI az iparosodás előtt kisebb gyakoriságban fordult elö, és a vizsgált nomád vagy nagyállattartó populációk körében tapasztalt nagyobb gyakoriság hátterében életmódbeli és táplálkozási szokások állhatnak. Hershkovitz és munkatársai (1999) szerint a betegség több fokozatát különböztethetjük meg (a típuseloszlás szerinti gyakorisági adatokat az M21. táblázat mutatja be). Kehida-Fövenyes esetén az esetek többségében A-típusú HFI-vel találkozhattunk. A mintában legsúlyosabbnak számító C-típus egy 40-50 éves egyén esetében (ltsz: 2017.4.10, 11. sír) volt tapasztalható, aki a morfológiai jellegei alapján valószínüleg férfi lehetett (5. ábra).

A kóros csontburjánzások minden esetben az adultus korcsoport éveinek második felében, vagy afelett jelentkeztek (M22. táblázat). Mindez várható eredmény, tekintve, hogy a betegséget a menopauza után bekövetkező hormonális változásokhoz kötik (Hershkovitz és mtsai 1999). 


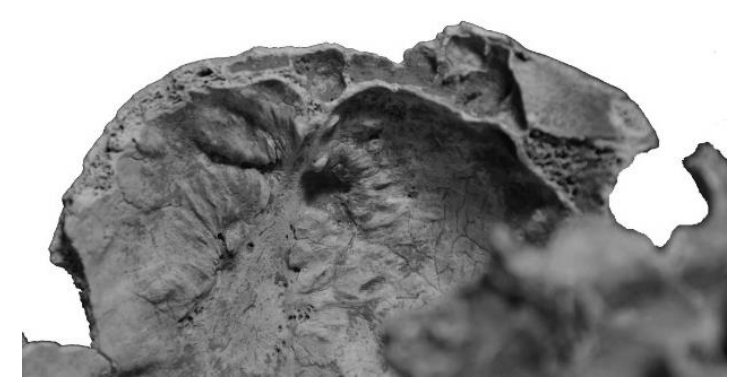

5. ábra: C-típusú HFI egy férfi(?) homlokcsontjának belső felszínén (11. sír, ltsz: 2017.4.10)

Fig. 5: Type C HFI on the endocranial surface of the frontal bone in a male (?; grave no: 11, inv. no: 2017.4.10)

Nem specifikus fertözések. A nem specifikus fertőzések nyomait legtöbbször csonthártyagyulladás, csontvelőgyulladás, csontgyulladás, illetve a koponya belső felszínén lévő léziók formájában láthatjuk (Ortner 2003). A csonthártyagyulladás nem csak fertőzés által alakulhat ki, paleopatológiában okát nem mindig lehet a pontosan megállapítani. Kialakulhat traumás behatás, tumor, ízületi betegség, vagy dysplasia miatt is (Chen és mtsai 2012, Weston 2011).

A serpens endocrania symmetrica (SES) elnevezésű endokraniális lézió, valamint periosteális újcsontképződés jelenlétét is vizsgáltuk. Utóbbi többször is előfordult a populációban. Kóros újcsontképződés 8 gyermeknél, míg nőknél és férfiaknál a vizsgálható esetek mintegy felében volt (M23. táblázat). SES egy felnőtt nő és négy gyermek maradványain volt (M24. táblázat). A környezeti hatásokra érzékenyebben reagáló gyermeki szervezet lehet a gyakoribb előfordulás oka.

Osteomyelitis volt megfigyelhető egy 40-50 éves férfi (ltsz: 2018.2.58, 75. sír), egy 25-39 éves nő (ltsz: 2017.4.19, 19. sír), illetve egy 30-45 éves nő (ltsz: 2018.2.36, 53. sír) esetében.

Egy esetben (ltsz: 2019.1.29) súlyos, az egész csontot átható gyulladást figyeltünk meg egy nem meghatározható nemű felnőtt egyén sípcsontján (M37. ábra). A csontról CT felvétel is készült (M38-39. ábra), amelyen mind a rendezetlen felrakódott csontállomány, mind a kéregállomány magas fokú vaszkularizáltságot mutatott (Kiss és mtsai 2019).

Specifikus fertőzés. Egy 25-35 éves nő (ltsz: 2018.2.75, 89. sír) maradványainak vizsgálata közben egy lehetséges specifikus fertőzés következtében kialakult elváltozás nyomait azonosítottuk. A két combcsont és két tibia felszínén gyógyult, illetve utóbbi két csont esetén aktív perioszteális gyulladás nyomai is észrevehetők. A két fibula disztális végén csontos összenövés nyomai (ankylosis) is azonosíthatók. Bizonyos lábközépcsontok és ujjpercek leprás fertőzésre utaló morfológiai jegyeket viselnek. Két lábközépcsont is gyulladás jeleit mutatja, amelyböl a bal második metatarsus disztális fele erősen atrofizált (6. ábra). A vélhetően vele egy, vagy szomszédos ujjsugárban elhelyezkedő lábujjpercek egésze és ezzel együtt ízülete is erősen deformált. Az eset kapcsán felmerülhet a leprás fertőzés, mint a tüneteket kiváltó ok. A késő avar kori nőnél rhinomaxilláris tünet nyomai nem jelentkeznek, amely alapján a feltételezett fertőzés egy kevésbé tipikus megjelenési formáját láthatjuk. A lepra egyértelmü diagnózisához molekuláris vizsgálatok nyújthatnak majd biztos információkat. 
Daganatos elváltozások. A „button osteoma” elnevezésü, a koponya külső felszínére jellemző jóindulatú neoplasztikus képződmény egy férfi (ltsz: 2018.2.56, 71. sír) és egy nő (ltsz: 2018.2.11, 34. sír) esetében volt azonosítható.

Egy 40-50 éves maturus férfi (ltsz: 2017.4.9, 9/B. sír) esetében a vázrendszer több pontján áttétet adó (7-9. ábra, M40-44. ábra), nagy valószínúséggel lágyrészből kiinduló daganatot véleményeztünk (Hajdu és mtsai 2017, Kiss 2018, Kiss és mtsai 2018, 2019).

A vázrendszeren kóros oszteoblaszt és oszteoklaszt aktivitás, valamint perioszteális reakció nyoma is megfigyelhető (M40. ábra) A tumor miatt fokozott oszteoklaszt aktivitás látható mindkét acromionon, illetve a koponyán lítikus léziók formájában (M41. ábra). Kóros csontépítő folyamat figyelhető meg több borda, csigolya, a bal comb feje (7. ábra), a bal radius proximális vége, és a medence esetében. Perioszteális reakció látható a bal medence és a jobb halántékcsont felszínén.

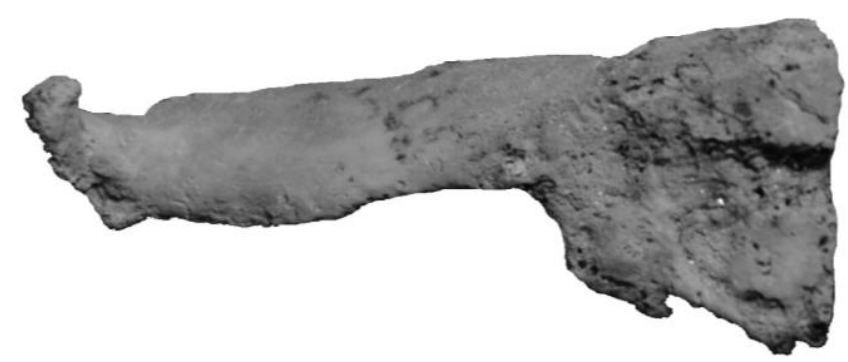

6. ábra: Egy lehetséges leprás fertőzés eredményeképpen kialakult atrofizált bal 2. metatarsus (89. sír, ltsz: 2018.2.75)

Fig. 6: A possible case of leprosy manifested in athrophic second metatarsal (grave no: 89, inventory no: 2018.2.75)

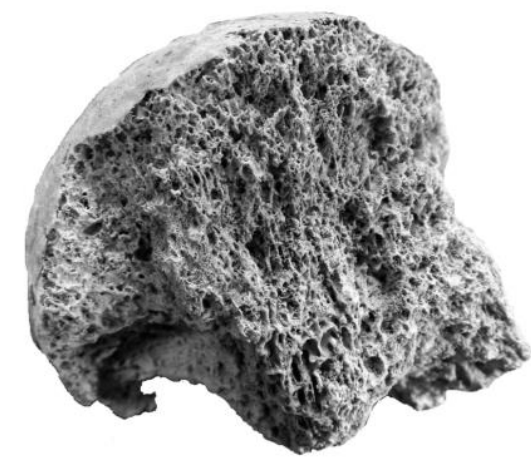

7. ábra: A bal oldali combcsont fejében látható kóros mértékủ oszteoblaszt aktivitás által átépült csontszerkezet (9/B. sír, ltsz: 2017.4.9)

Fig. 7: Femoral head from the left side showing pathological osteoblastic activity (grave no: 9/B, inventory no: 2017.4.9)

A radiológiai felvételek (8. ábra, M42-44. ábra) makroszkóposan nem észrevehető elváltozásokat is szemünk elé tárnak: több makroszkóposan nem érintett borda, valamint a bal radius diafízisének (M42. ábra) belsejében megbúvó tumoros szövet képe ábrázolódik. A koponya állományában button sequestrum látható (M43. ábra), amelyhez 
hasonló elváltozást például Micciché és kollégái (2018) írtak le korábban metasztatikus lágyrész tumor esetén, és amely lézió ritkán fordul elő myeloma multiplex fennállásakor. A pásztázó elektronmikroszkópos felvételek (egy a bordából vett minta esetén) a normál csontszövet között megülő tumoros sejtek és átalakult csontszövet maradványait mutatják (9. ábra).

Fejlödési rendellenességek. Sacralisatio-t két felnőtt férfi és egy felnőtt nő esetén, míg lumbalisatio-t egy gyermek és egy felnőtt férfi maradványain azonosítottunk. Sacrum bifidum volt kimutatható egy felnőtt nő keresztcsontján. Egy 20-25 éves nőnél (ltsz: 2019.1.6, 87. sír) a tibia és fibula proximális ízesülésének primer formájával lehetett találkozni.

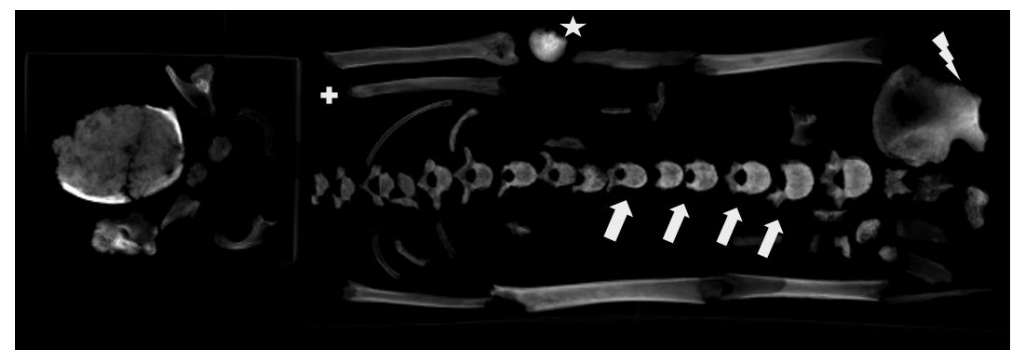

8. ábra: A 2017.4.9 leltári számú tumoros egyén maradványainak CT felvételből készült rekonstrukciója (Avg) jól mutatja a tumor által indukált oszteoblaszt tevékenység legfőbb helyeit: a csigolyákon (nyíl), bal combcsont fején (csillag), medencében (villám) és az orsócsont (plusz jel) proximális végén és diafízisében (a csontok nem anatómiai sorrendben kerültek a vizsgálóasztalra.) Fig. 8: Average reconstruction made from the CT scan of maturus male (grave no: 9/B; inventory no: 2017.4.9): hiperdensity of vertebraes (arrow), left femoral head (star), pelvic bones (lightning) and radius (plus) indicates pathological osteoblastic activity (bones are not in anatomic order)

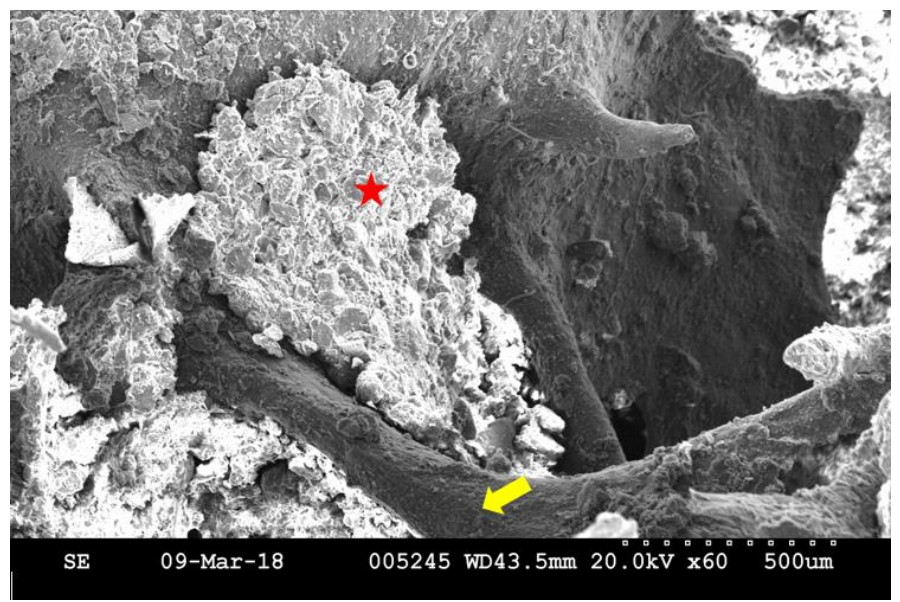

9. ábra: A tumoros egyén (9/B. sír, ltsz: 2017.4.9) bordájából vett minta elektronmikroszkópos felvételén a normál trabeculákat (nyíl) körbevevő strukturálatlan csontszövet (csillag) látható Fig. 9: SEM examination performed on sample taken from a rib maturus male diagnosed with metastatic cancer (grave no: 9/B, inventory no: 2017.4.9): besides normal trabeculae (arrow) unstructured bone tissue can be seen (star) 
Egy 35-45 éves nő esetében (ltsz: 2017.4.16, 17/B. sír) nyaki bordákat találtunk, míg egy 20-35 éves nő (ltsz: 2018.2.59, 76. sír) jobb felső bölcsességfogának gyökerén zománcgyöngyöt vettünk észre. Egy 35-45 éves férfi (ltsz: 2018.2.60, 78. sír) koponyáján egy kóros mértékben meghosszabbodott, $50 \mathrm{~mm}$ hosszú processus styloideus utal Eagleszindrómára. A bal íróvesszőnyúlvány nem volt vizsgálható.

Traumás elváltozások. A csigolyaív törését (spondylolysis) 2 férfi (ltsz: 2017.4.2, 4. sír; ltsz: 2018.2.60, 78. sír) és 3 nő (ltsz: 2017.4.22, 22. sír; 2018.2.75 89. sír; 2018.2.78, 100. sír) esetén diagnosztizáltuk. Mind az öt egyénnél megfigyeltünk gyógyulásnyomot, ugyanakkor a törési élek nem fuzionáltak. Egy 45-60 éves férfi (ltsz: 2018.2.56, 71. sír) vállízületében luxatio-t azonosítottunk. A ficam során a jobb humerus feje nem tért vissza a vállízületi vápába. Helyette a lapocka elülső felszínén jött létre egy patológiás vápa, amely ízfelszínén hasonlóan a karcsont fejéhez nagymértékü eburnáció figyelhető meg (M44. ábra). A jobb lapockáról és karcsontról készült CT felvételen hiperdenzitás képében figyelhető meg a csontszerkezet reakciója a patológiás vápa közvetlen szomszédságában. Az M45. ábra szemlélteti a kóros vápa alatti gyulladt, átépült csontszerkezetet a normál vápa környezetéhez képest.

A 2018.2.91. leltári számú (117/A. sír), 40-55 éves férfi bordatöredékén atrófia látható, amelyet traumás behatás okozhatott. Több egyén koponyáján figyelhető meg traumás behatás nyoma. A 2018.2.56. leltári szám alá került 45-60 éves férfi (71. sír) bregma pontjától balra egy 10x6 mm-es traumás eredetủ depresszió látható.

Gyulladt, de gyógyult trauma nyoma látható egy 40-55 éves nő falcsontjának 20x15 mm-es területén (ltsz: 2017.4.18, 18/B. sír). Egy 20-30 éves fiatal nő (ltsz: 2018.2.102., 129. sír) orrcsontján pedig gyógyult törés figyelhető meg.

A 2019.1.7. leltári számú 30-40 éves férfi (119. sír) homlokán lévő sutura metopica vonalában depresszió figyelhető meg (10. ábra). A benyomat környékén a csont külső és belső felszínén nem látható gyulladás nyoma. A koponya radiológiai vizsgálata (Kiss és mtsai 2019) azonban egy érdekes léziót tárt fel a szivacsos állományban (11. ábra).

Nem a depresszió alatt, hanem attól balra helyezkedik el egy gyürủ alakú hiperdenz elváltozás, amely lehet osszifikálódott vérömleny (cephalhematoma), fibrózus diszplázia vagy valamilyen jóindulatú térfoglaló folyamat (intraosseális osteoma) is. Elképzelhetö, hogy a léziónak nincs köze a homlok benyomatához, de az sem kizárható, hogy a trauma miatt jött létre a koponya belsejében a lézió, mint vérömleny, illetve a homlok mélyedése a sutura metopica összezáródását is megakadályozta. Szintén traumára utalhat a férfi bal orsócsontjának jelentős tengelyeltérést eredményező gyógyult törése is.

Több egyén végtagján gyógyult pre- vagy antemortem töréseket lehetett megfigyelni. Ante- vagy perimortem sérüléseket nem azonosítottunk az embertani leletanyag vizsgálata közben.

A 2018.2.10 leltári számú 4-6 éves gyermek (33/B. sír) jobb karcsontjának anatómiai nyakánál zöldgally törés nyomait lehetett felfedezni. Egy 35-45 éves férfi (ltsz: 2018.2.26, 45. sír) bal singcsontjának disztális végén figyelhetö meg tengelyeltérést nem okozó gyógyult törés. A korábban már említett 2018.2.58 leltári számú egyénnél (75. sír) nem zárható ki az osteomyelitis, ugyanakkor a 4035-50 éves férfi singcsontja disztális végén észlelhető elváltozás oka korábban szerzett törés is lehet. A 2018.2.11 leltári számú maturus korú nő (34. sír) szárkapocscsontján diagnosztizáltunk gyógyult törést. 


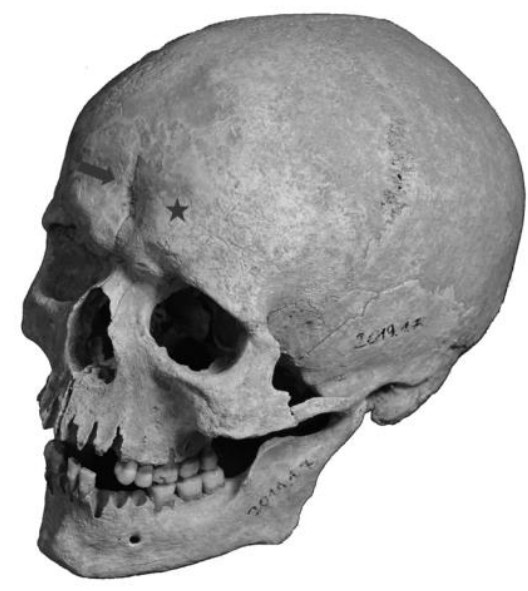

10. ábra: Egy 30-40 éves férfi homlokán a perzisztáló sutura metopica (nyíl) vonalában depresszió figyelhető meg, a csillag a külsőleg nem látható lézió elhelyezkedésére mutat, a homlokcsonton nem látható gyulladás a CT felvételen (119. sír, ltsz: 2019.1.7)

Fig. 10: A 30-40 years old male possessing depression along metopic suture (arrow), the star indicates the intracortical lesion, while inflammation on the frontal bone cannot be seen on CT scans (grave no: 119, inventory no: 2019.1.7)

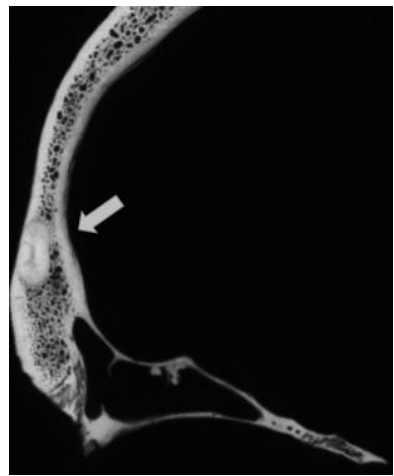

11. ábra: A homloknál intraosszeális lézió (nyíl), oszteoma ábrázolódik a szagittális síkban készült CT felvételen

(119. sír, ltsz: 2019.1.7) Fig. 11: Intraosseal lesion (osteoma) can be seen on CT scan (arrow; grave no: 119, inventory no: 2019.1.7)

Anatómiai variációk. A késő avar kori temető elemzése közben több anatómiai variáció meglétét vagy hiányát jegyeztük fel mind gyermekek, mind felnőttek esetében (M25-26. táblázat). A posztkraniális vázon a nyaki csigolyák foramen transversariumának két vagy háromfelé való osztottságát, a karcsonton a foramen supratrochlearis, a taluson pedig egy járulékos csont, az os trigonum jeleit kerestük. A koponyán a következő variációkat vizsgáltuk: ossa suturae coronalis, os bregmatum, ossa suturae sagittalis, os lambdae, ossa wormiana, os incae, os astericum, torus mandibularis, torus maxillaris, os epiptericum és sutura metopica. Gyermekeknél a leggyakrabban azonosítható variáció az ossa wormiana volt, amelyet a nyaki csigolyákon előforduló két vagy háromosztatú foramen transversarium követett. Más variációk elvétve vagy egyáltalán nem jelentkeztek.

Ha gyakoriság szerint rangsoroljuk a variációkat, akkor a következő sorrendet kapjuk:

Férfiak: 1. ossa wormiana, 2. os lambdae, 3. foramen transversarium osztottsága, 4. os astericum, 5. foramen supratrochlearis, ossa suturae sagittalis, os incae. Nők: 1. ossa wormiana, 2. foramen supratrochlearis, 3. foramen transversarium osztottsága, 4. os astericum, 5. os incae, os lambdae. A két nemnél összesen: 1. ossa wormiana, 2. foramen transversarium osztottsága, 3. foramen supratrochlearis, 4. os lambdae, 5. os astericum.

\section{Összefoglalás}

Kutatásunk során Kehida-Fövenyes 8-9. századi népességének 167 leletét vizsgáltuk. A 141 síros temetőt a 8 . század utolsó harmadától a 9. század első feléig használták. 
Az egyének jó megtartású maradványai lehetővé tették a részletes demográfiai elemzést. Összesen 60 gyermeket, 33 férfit, 50 nőt és 16 ismeretlen nemü felnőtt egyént azonosítottunk. A neonatus korcsoportba tartozó egyének száma alulreprezentált, a férfiak és nők aránya pedig nem mutat egyensúlyt a populációban. Gyermekeknél az infans I-es korcsoportba sorolható a legtöbb egyén, és a Coale és Demény (1966) féle korrekció nélküli halálozási valószínüség az 1-4, illetve 5-9 éves korcsoportoknál volt a legmagasabb $(0,16)$. Felnőtteknél a nőket a legtöbb korcsoportban magasabb elhalálozási valószínüség jellemezte, amely valószínüleg a szüléssel és terhességgel kapcsolatos fiziológiás és patológiás stressznek köszönhető. A férfiak $(168,55 \mathrm{~cm})$ és nők $(158,35 \mathrm{~cm})$ átlagos testmagassága nem tér el jelentősen a dunántúli és Kárpát-medencei, avar populációkra jellemző átlagos testmagasságtól.

Összesen 23 férfi és 39 nö koponyáján lehetett méréseket elvégezni, amelyek között 8 férfi és 8 nő koponyája volt alkalmas Mahalanobis távolság számítására és a kehidai népesség esetleges párhuzamainak keresésére. Ennek megfelelően a férfiak koponyájának metrikus jellemzői szignifikánsan különböznek Pókaszepetk népességének férfiaitól, míg a leginkább hasonló csoport Keszthely Ödenkirche-Flur férfiai voltak. Kehida-Fövenyes női sorozata szignifikánsan különbözött Garabonc Ófalu I. közösségének női szériájától. A legközelebbi analógia Keszthely-Fenékpuszta volt. A népességek közötti becsült biológiai távolságok alapján a férfiak vagy közeli felmenőik többsége más régióból származtatható.

A taxonómiai elemzések alapján a populációt europid egyének alkották, ugyanakkor több esetben volt felfedezhető valamilyen enyhe mongoloid jelleg. A két leggyakoribb típus a cromagnoid-A és mediterrán volt. A vizsgált koponyák döntő része dolichokran volt, ugyanakkor egy férfi és két nő brachykran koponyával rendelkezett. Tisztán mongolid egyént nem figyeltünk meg a vizsgálati anyagban. Taxonómiai szempontból Kehida-Fövenyes embertani képe beleillik a térség antropológiai arculatába.

A paleopatológiai vizsgálatok során több életmódhoz köthető és degeneratív okokból kialakuló elváltozást diagnosztizáltunk. A nőknél megfigyelhető gyakoribb enthesopathiás és ízületi elváltozások a két nem által végzett különböző típusú munkára utalhatnak. A gerinc különböző léziói között ugyanakkor nem mutatkozik meg nemi különbség.

A hematogén elváltozások alapján a nök érzékenyebbek voltak a környezeti faktorokból származó stresszre, mint a férfiak. Ennek oka hasonlóan ahhoz, amit a magasabb elhalálozási valószínüségnél láthattunk, a női nem biológiai sajátságaira vezethető vissza: a szülésre és menstruáció miatti vashiányra. A felismert vérképzési zavarok száma alapján a népesség környezeti stresszre legérzékenyebb tagjai a fejlődésben lévő gyermekek voltak.

A metabolikus eredetű zavarok közül a hyperostosis frontalis interna előfordulását a férfiakon és a nőkön egyaránt meg lehetett figyelni, jellemzően az adultus-maturus és maturus korcsoportokban. Ahogyan az az irodalmi adatok szerint is várható (Szeniczey és mtsai 2019), a nőket gyakrabban érintette az elváltozás. Daganatos elfajulások közül az észlelt jóindulatú button oszteomákon kívül egy esetben lágyrészből származó csontmetasztázissal találkoztunk. Gyermekeknél és felnőtteknél is nem specifikus fertőzések nyomai is megfigyelhetők voltak perioszteális újcsontképződés, osteomyelitis, osteitis, sinusitis maxillaris, illetve SES (serpens endocrania symmetrica) képében.

Egy esetben leprás fertőzést feltételeztünk, azonban a biztos diagnózis felállításához molekuláris vizsgálatokra lesz szükség. A Mycobacterium leprae fertőzés bebizonyosodása új adattal szolgálna a kórokozó avar korban való elterjedésével 
kapcsolatban, ugyanis mindezidáig nem jelentettek leprás esetet a Nyugat-Dunántúl térségéből. Az avar korból leprás megbetegedések a dél alföldi Kiskundorozsma, Szarvas, Orosháza, a Duna-Tisza közi Hajós, valamint a dunántúli Kaposvár 61-es út 2. lelöhely területéről ismertek (Marcsik és mtsai 2007, 2009, 2014, Pálfi és Molnár 2009, Németh 2010; Németh és mtsai 2015).

A történeti embertani szériákban általánosnak számító fejlődési rendellenességek mellett (sacralisatio, lumbalisatio, sacrum bifidum) az igen ritka tibiofibularis synostosisszal is találkoztunk. A vizsgált személyeket kisebb traumák érték koponyájukon, valamint több esetben valamely hosszú csont jól regenerálódott, a csontok alapján szövődménymentes törése volt megfigyelhető.

Perimortem traumás behatással, amely erőszakos cselekményre utalt volna, nem találkoztunk, így valószínüsíthető, hogy a vizsgált populáció élete mentes volt a komoly konfliktusoktól. Gyermekek és felnőttek esetén is feljegyeztük a koponya és posztkraniális váz több elemének anatómiai variációját. Felnőtteknél mindkét nemnél az ossa wormiana volt a leggyakoribb variáció. A multidiszciplinaritás jegyében azokban az esetekben, amikor szükséges volt, paleoradiológiai elemzések segítségével igyekeztünk pontosabb diagnózist adni a kóros elváltozásokról.

Köszönetnyilvánítás: Köszönettel tartozunk a Bolyai Kollégiumnak, a Bolyai Kollégiumért Alapítványnak, az Emberi Erőforrások Minisztériuma által meghirdetett Nemzet Fiatal Tehetségeiért Ösztöndíj 2018 (NTP-NFTÖ-18-B-0053) pályázatnak, az NKFIH Horvát-Magyar bilaterális projektjének (TÉT_16-1-2016-0020) és az NKFI 111853 azonosítószámú OTKA projektjének.

\section{Irodalom}

Acsádi, Gy., Nemeskéri, J. (1970): History of human life span and mortality. Akadémiai Kiadó, Budapest. pp. 346.

Alekszejev, V.P., Debec, G.F. (1964): Kraniometrija. Izd. Nauka, Moszkva.

Aufderheide, A.C., Rodríguez-Martín, C. (1998): The Cambridge encyclopedia of human paleopathology. Cambridge University Press, Cambridge. pp. 478.

Bartucz, L. (1930): Die anthropologischen Ergebnisse der Ausgrabungen von Jutas und Öskü. Skythica, 4: 1-16.

Bernert, Zs. (2003): Anthropological analysis of the Avar Period cemetery of Kereki-Homokbánya (Kereki Sand-pit). Annales historico-naturales Musei nationalis hungarici, 95: 225-309.

Bernert, Zs. (2005): Paleoantropológiai programcsomag. Folia Anthropologica, 3: 71-74.

Bernert, Zs., Évinger, S., Hajdu, T. (2007): New data on the biological age estimation of children using bone measurements based on historical populations from the Carpathian Basin. Annales historico-naturales Musei nationalis hungarici, 99: 199-206.

Bernert, Zs., Évinger, S., Hajdu, T. (2008): Adatok a gyermekek életkorbecsléséhez a Kárpátmedencei történeti népességek gyermekhalottainak csontméretei alapján. Anthropologiai Közlemények, 49: 43-50.

Bottyán, L.O. (1975): Pókaszepetk kora-avarkori temetőjének antropológiai értékelése. Anthropologia Hungarica, 14: 5-56.

Brooks, S., Suchey, J.M. (1990): Skeletal age determination based on the os pubis: a comparison of the Acsadi-Nemeskeri and Suchey-Brooks methods. Human Evolution, 5: 227-238. DOI: https://doi.org/10.1007/BF02437238 
Buckberry, J.L, Chamberlain, A.T. (2002): Age estimation from the auricular surface of the ilium: a revised method. American Journal of Physical Anthropology, 119: 213-239. DOI: https://doi.org/10.1002/ajpa.10130

Chhem, R.K., Brothwell, D.R. (2008): Paleoradiology - Imaging Mummies and Fossils. Springer, Berlin. pp. 163.

Chen, E.M., Masih, S., Chow, K., Matcuk, G., Patel, D. (2012): Periosteal reaction: review of various patterns associated with specific pathology. Contemporary Diagnostic Radiology, 35: 1-6. DOI: https://doi.org/10.1097/01.CDR.0000418464.79923.5c

Coale, A.J., Demény, P. (1966): Regional modell life tables and stable populations. Princeton University Press, Princeton. pp. 871.

Darroch, J.N., Mosimann, J.E. (1985): Canonical and principal components of shape. Biometrika, 72: 241-252.

Dar, G., Masharawi, Y., Peleg, S., Steinberg, N., May, H., Medlej, B., Peled, N., Hershkovitz, I. (2010): Schmorl's nodes distribution in the human spine and its possible etiology. European Spine Journal, 19(4): 670-675. DOI: https://doi.org/10.1007/s00586-009-1238-8

Éry, K. (1982): Újabb összehasonlító statisztikai vizsgálatok a Kárpát-medence 6-12. századi népességeinek embertanához. Veszprém megyei Múzeumok Közleményei, 16: 35-86.

Éry, K. (1992): Anthropologische Untersuchungen an drei Populationen aus dem 9. Jahrhundert in Westungarn. Antaeus, 21: 337-381.

Éry, K. (1998): Length of limb bones and stature in ancient populations in the Carpathian Basin. Humanbiologia Budapestinensis, 26: 1-87.

Éry, K. (2001): Késő avarkori népesség Zalakomár határából. Zalai Múzeum, 10: 141-150.

Éry, K., Kralovánszky, A., Nemeskéri, J. (1963): Történeti népességek rekonstrukciójának reprezentáció. Anthropologiai Közlemények, 7: 41-90.

Évinger, S., Bernert, Zs. (2005): Anthropological investigation of the Avar Period cemetery of Kaposvár Road 61, Site No. 26 (Hungary). Annales historico-naturales Musei nationalis hungarici, 97: 261-319.

Fazekas, G., Kósa, F. (1978): Forensic fetal osteology. Akadémiai Kiadó, Budapest. pp. 414.

Ferembach, D., Schwidetzky, I., Stloukal, M. (1979): Empfehlungen für die Alters- und Geschlechtsdiagnose am Skelett. Homo, 30: 1-32.

Fóthi, E. (1984): A Kárpát-medence avar korának összehasonlító embertani vizsgálata. Móra Ferenc Múzeum Évkönyve, 85: 483-501.

Fóthi, E. (1988): The anthropological investigation of the Avar-age cemetery of Fészerlak. Anthropologia Hungarica, 20: 31-53.

Fráter, L. (2015): Radiológia. Medicina Könyvkiadó, Budapest. pp. 542.

Hajdu, T., Marcsik, A., Szeniczey, T., Kiss, K., Bernert, Zs., Zádori, P., Buczkó, K., Dallos, Zs., Dódony, I., Takács-Vellai, K., Molnár, E. (2017): Paleooncological research on historical populations from the Carpathian Basin "Homines, Funera, Astra" - Death and Children from Prehistory to Middle Ages. International Symposium on Funerary Anthropology. Alba Iulia, Románia.

Hershkovitz, I., Greenwald, C., Rothschild, B.M., Latimer, B., Dutour, O., Jellema, L.M., WishBaratz, S., (1999): Hyperostosis frontalis interna: an anthropological perspective. American Journal of Physical Anthropology, 109: 303-325. DOI: https://doi.org/10.1002/(SICI)10968644(199907)109:3<303::AID-AJPA3>3.0.CO;2-I

Iscan, M.Y., Loth, S.R., Wright, R.K. (1984): Age estimation from the rib by phase analysis: white males. Journal of Forensic Sciences, 29: 1094-1104. DOI: https://doi.org/10.1520/JFS11776J

Iscan, M.Y., Loth, S.R., Wright, R.K. (1985): Age estimation from the rib by phase analysis: white females. Journal of Forensic Sciences, 30: 853-863. DOI: https://doi.org/10.1520/JFS11018J

Jaffe, H.L. (1975): Metabolic, degenerative and inflammatory diseases of bone and joints. Lea and Febiger, Philadelphia, USA. pp. 1101.

Józsa, L., Pap, I. (1991): Vashiányos anaemia a honfoglalás és az Árpádok korában. Orvosi Hetilap, 28: 1544-1545. 
Keat, E.T., Anderson, W.M. (1994): Atlas of Normal Roentgen Variants That May Simulate Disease. 8th Edition. Saunder, Philadelphia, USA. pp. 1344.

Kiss, K. (2018): A possible case of secondary cancer from Kehida-Fövenyes. Horvát-Magyar Bilaterális Projekt Workshopja. ELTE, Embertani Tanszék, Budapest.

Kiss, K., Szeniczey, T., Karlinger, K., Mészáros, Kis, Zs., Szvák, E., Molnár, E., Marcsik, A., Sklánitz, A., Szabó, L., Dallos, Zs., Kovács Kis, V., Buczkó, K., Hajdu, T. (2018): A possible case of metastatic cancer from Kehida-Fövenyes (7-8th century AD). 22nd European Meeting of the Paleopathology Association, Zagreb, Croatia.

Kiss, K., Szeniczey, T., Karlinger, K., Mészáros, Kis, Zs., Szvák, E., Marcsik, A., Sklánitz, A., Szabó, L., Hajdu, T. (2019): Kehida-Fövenyes késö avar kori (7-8. század) embertani anyagának paleoradiológiai vizsgálata. XXIV. Bolyai Konferencia, Budapest.

Lipták, P. (1959): The "Avar Period" Mongoloids in Hungary. Acta Archaeologica Academiae Scientiarum Hungaricae, 10: 251-279.

Lipták, P. (1965): On the taxonomic method in the paleoanthropology (historical anthropology). Acta Biologica Szegediensis, 11: 169-183.

Lombay, B. (2013, Szerk.): Radiopathológia - tankönyv képalkotó diagnosztikai analitikus hallgatók számára. Miskolci Egyetem, Miskolc. pp. 397

Loth, S.R, Henneberg, M. (1996): Mandibular ramus flexure: a new morphologic indicator of sexual dimorphism in the human skeleton. American Journal of Physical Anthropology, 99: 473-485. DOI: https://doi.org/10.1002/(SICI)1096-8644(199603)99:3<473::AID-AJPA8>3.0.CO;2-X

Lovejoy, C.O., Meindl, R.S., Pryzbeck, T.R., Mensforth, R.P. (1985): Chronological metamorphosis of the auricular surface of the ilium: a new method for the determination of adult skeletal age at death. American Journal of Physical Anthropology, 68: 15-28.

Mahalanobis, P.C. (1936): On the generalised distance in statistics. Proceedings of the Indian National Science Academy, 12: 49-55.

Mann, R.W., Jantz, R.L., Bass, W.M., Willey, P.S. (1991): Maxillary suture obliteration: a visual method for estimating skeletal age. Journal of Forensic Sciences, 36: 781-791. DOI: https://doi.org/10.1520/JFS13088J

Mann, R.W., Hunt, D.R. (2005): Photographic Regional Atlas of Bone Disease - A Guide to Pathologic and Normal Variation in the Human Skeleton. Charles C. Thomas Publisher, Springfield. pp. 432.

Mann, R.W., Hunt, D.R., Lozanoff, S. (2016): Photographic Regional Atlas of Non-Metric Traits and Anatomical Variants in the Human Skeleton. Charles C. Thomas Publisher, Springfield. pp. 744.

Marcsik, A. (1975): Presumed etiology of a bone change. Anthropologiai Közlemények, 19: 47-53.

Marcsik, A., Molnár, E., Ösz, B. (2007): Specifikus fertôzö megbetegedések csontelváltozásai történeti népesség körében. JATE Press, Szeged. pp. 46.

Marcsik, A., Molnár, E., Ősz, B., Donoghue, H., Zink, A., Pálfi, Gy. (2009): Adatok a lepra, tuberculosis és syphilis magyarországi paleopatológiájához. Folia Anthropologica, 9: 5-34.

Marcsik, A., Balázs, J., Molnár, E. (2014): Újabb adatok a lepra elterjedéséhez az avar korban (Duna-Tisza köz) esetismertetés. Folia Anthropologica, 13: 81-85.

Martin, R., Saller, K. (1957): Lehrbuch der Anthropologie. Bd. 1. Gustav Fischer Verlag, Stuttgart.

Meindl, R.S., Lovejoy, C.O. (1985): Ectocranial suture closure: a revised method for the determination of skeletal age at death. American Journal of Physical Anthropology, 68: 57-66.

Mende, B.G., Kirinó, K. (2014): Antropologische Analyse der Skelettreste aus dem frühmittelalterlichen Gräberdeld (6-7. Jh) von Keszthely-Fenékpuszta, Ödenkirche-Flur. In: Müller, R. (Ed.) Die Gräberdelder von Keszthely-Fenékpuszta, Ödenkirche-Flur. Budapest, Laipzig, Keszthely. pp. 209-256.

Micciche, R., Carotenuto, G., Sìneo, L. (2018): The utility of 3D medical imaging techniques for obtaining a reliable differential diagnosis of metastatic cancer in an Iron Age skull. International Journal of Paleopathology, 21: 41-46. DOI: https://doi.org/10.1016/j.ijpp.2017.03.006 
Németh, Cs.E. (2010): Egy Árpád-kori temetö embertani anyagának demográfiai és paleopatológiai vizsgálata. Szakdolgozat. ELTE, Embertani Tanszék, Budapest.

Németh, Cs.E., Bernert, Zs., Gallina, Zs., Varga, M., Pap, I., Hajdu, T. (2015): Kaposvár 61-es út 2. lelőhely Árpád-kori embertani anyagának paleodemográfiai és paleopatológiai vizsgálata. Anthropologiai Közlemények, 56: 61-90.

Nikita, E. (2017): Ostearcheology. A Guide to the Macroscopic Study of Human Skeletal Remains. Academic Press, London. pp. 462.

Ortner, D.J. (2003): Identification of a pathological conditions in human skeletal remains. Academic Press, San Diego. pp. 605.

Pohl, W. (2018): The Avars. A Steppe Empire in Central Europe, 567-822. Cornell University Press, Ithaca and London. pp. 636.

Pálfi, Gy., Molnár, E. (2009): The Paleopathology of specific infectious diseases from Southeastern Hungary: a brief overview. Acta Biologica Szegediensis, 53(2): 111-116.

Rogers, T.L. (1999): A visual method of determining the sex of skeletal remains using the distal humerus. Journal of Forensic Sciences, 44: 57-60.

Schinz, H.R., Case, J.T. (1952): Roentgen-diagnostics. Grune \& Stratton, New York.

Schour, I., Massler, M. (1941): The development of the human dentition. Journal of the American Dental Association, 28: 1153-1160.

Sjøvold, T. (1975): Some notes on the distribution and certain modifications of Mahalanobis generalized distance. Journal of Human Evolution, 4: 549-558. DOI: https://doi.org/10.1016/0047-2484(75)90155-4

Sjøvold, T. (1990). Estimation of stature from long bones utilizing the line of organic correlation. Journal of Human Evolution, 5: 431-444. DOI: https://doi.org/10.1007/BF02435593

Stloukal, M., Hanáková, H. (1978): Die Lange der Langsknochen altslawischer Bevölkerungen unter besonderer Berücksichtigung von Wachstumsfragen. Homo, 29: 53-69.

Suskovics, Cs. (1993): Siófok-Kiliti avarkori népességének embertani vázlata. Anthropologiai Közlemények, 35: 61-81.

Szeniczey, T. (2019): A Kelet-Dunántúl avar kori népességváltozásainak történeti embertani vizsgálata. PhD doktori értekezés. Eötvös Loránd Tudományegyetem, Budapest.

Szeniczey, T., Marcsik, A., Ács, Zs., Balassa, T., Bernert, Zs., Bakó, K., Czuppon, T., Endrődi, A., Évinger, S., Farkas, Z., Hlavenková, L., Hoppál, K., Kiss, Cs.K., Kiss, K., Kocsis, K., Kovács, L.O., Kovács, P., Köhler, K., Hajdu, T. (2019): Hyperostosis frontalis interna in ancient populations from the Carpathian Basin - a possible relationship between lifestyle and risk of development. International Journal of Paleopathology, 24: 108-118. DOI: https://doi.org/10.1016/j.ijpp.2018.10.003

Szőke, B.M. (2002): Avar kori központok a határ mentén. In: Vándor, L. (Szerk.) Központok a Zala mentén: a Göcseji Múzeum állandó kiállítása: katalógus. Göcseji Múzeum, Zalaegerszeg. pp. 65-87.

Szőke, B.M. (2003): A kései avar kor (7-8. század fordulója - 811). In: Visy, Zs. (Szerk.) Magyar Régészet az ezredfordulón. Nemzeti Kulturális Örökség Minisztériuma - Teleki László Alapítvány, Budapest. pp. 308-312.

Szőke, B.M. (2004): Archäologische Angaben zu den ethnischen Verhältnissen Pannoniens am Anfang der Karolingerzeik. In: Fusek, G. (Red.): Zbornik na pocest Dariny Bialekovej. Nitra, Slovakia. pp. 371-382.

Szöke, B.M. (2014): The Carolingian Age in the Carpathian Basin. Budapest. pp. 141.

Szőke, B.M., Vándor, L. (2001): Kehida Fövenyes. In: Bencze, Z., Lőrinczy, G., Mráv, Zs., Rezi Kató, G., Tomka, G., Wollák, K. (Szerk.): Régészeti kutatások Magyarországon. Budapest.

Todd, T.W. (1920): Age changes in the pubis bone: I. The male white pubis. American Journal of Physical Anthropology, 3: 285-334.

Todd, T.W. (1921): Age changes in the pubic bone. American Journal of Physical Anthropology, 4: $1-70$. 
Ubelaker, D.H. (1989): Human skeletal remains: excavation, analysis, interpretation. 2nd ed. Taraxacum, Washington. pp. 172

Varga, P., Bernert, Zs., Fóthi, E., Gyenis, Gy. (2003): Lipp Vilmos vezetésével feltárt, Keszthely környéki temetők embertani anyagának antropológiai elemzése. Békés Megyei Múzeumok Közleményei, 24-25: 449-477.

Waldron, T. (2008): Paleopathology (Cambridge Manuals in Archeology). Cambridge University Press, Cambridge. pp. 298.

Wenger, S. (1974): Déldunántúl avarkori népességének embertani problémái. Anthropologia Hungarica, 13: 5-89.

Wenger, S. (1977): Analyses anthropologiques de nouvelles decouvertes de Keszthely (Transdanubie) provenant de l'epoque avare. Anthropologia Hungarica, 15: 125-190.

Western, A.G., Bekvalac, J.J. (2017): Hyperostosis frontalis interna in female historic skeletal populations: age, sex hormones and the impact of industrialization. American Journal of Physical Anthropology, 162: 501-515. DOI: https://doi.org/10.1002/ajpa.23133

Weston, D.,A. (2011): Nonspecific infection in palaeopathology: interpreting periosteal reactions. In: Grauer, A.L. (Ed.) A companion to Paleopathology. Blackwell Publishing Ltd, New Jersey, USA. pp. 492-512.

Williams-Blangero, S., Blangero, J. (1989): Anthropometric variation and the genetic structure of the Jirels of Nepal. Human Biology, 61: 1-12.

Levelezési cím:

Mailing address:
Kiss Krisztián

Embertani Tanszék

Eötvös Loránd Tudományegyetem

Pázmány P. s. 1/c.

H-1117 Budapest

Hungary

kisskr@elte.hu
Hajdu Tamás

Embertani Tanszék

Eötvös Loránd Tudományegyetem

Pázmány P. s. 1/c.

H-1117 Budapest

Hungary

hajdut@elte.hu 
